\title{
A Survey Profile on Broiler Poultry Litter Production and Disposal in Tamil Nadu, India
}

\author{
M. Thirunavukkarasu ${ }^{1 *}$, K. Sivakumar ${ }^{2}$, V. Ramesh $^{2}$, M.R. Purushothaman ${ }^{2}$, \\ N. Murali ${ }^{2}$ and S. Mahimairaja ${ }^{1}$ \\ ${ }^{1}$ Department of Veterinary and Animal Sciences, Tamil Nadu Agricultural University \\ Coimbatore - 641 003, India \\ ${ }^{2}$ Veterinary college Research Institute, TANUVAS, Namakkal, India
}

*Corresponding author

\begin{tabular}{l} 
K e y w o r d s \\
$\begin{array}{l}\text { Environmental } \\
\text { degradation, Broiler } \\
\text { meat, Poultry } \\
\text { products }\end{array}$ \\
Article Info \\
$\begin{array}{l}\text { Accepted: } \\
\text { 07 November } 2019 \\
\text { Available Online: } \\
10 \text { December } 2019\end{array}$ \\
\hline
\end{tabular}

Keywords

Environmental degradation, Broiler meat, Poultry products

Article Info

Accepted:

Available Online:

10 December 2019
A Survey was undertaken with prepared interview schedule to study the profile of broiler poultry litter production and disposal. The data on farm profile, litter material, litter production and disposal were collected and analyzed. The frequency and percentage were worked out of the data collected. The survey revealed that 20.9 of the farmers were found to market the BPL to the traders operating in the locality $20 \%$ of farmers were found to market the BPL directly to the farmers, $10 \%$ of the farmers only had land resources to make use of the entire quantity of BPL produced in the farms. $27.3 \%$ of the respondents were found to sell BPL to the local farmers and use whenever the need for their agricultural operation and 21.8 $\%$ of the respondents were found to sell out the BPL directly to the farmers as well as the traders in addition to use in their farming operation.

\section{Introduction}

The Indian poultry industry consisting of broiler and eggs worth of INR 1494 billion in 2017 and the market is projected to reach INR 3775 billion by 2023 at a CAGR of $16.5 \%$ during 2018-2023. The country has exported $5,44,985.06$ MT of poultry products to the world for the worth of Rs. 687.31 crore/ 98.42 USD millions during the year 2018-2019
(Report, 2019). More than 80 percent of India's chicken output is produced by organized commercial farms. Major poultry companies have vertically integrated operations which comprise approximately 6070 percent of the total chicken production.

Broiler farming is successful with vertical integration (Mehta and Nambiar, 2008; Chatterjee and Rajkumar, 2015) and India is 
the $5^{\text {th }}$ largest producer in the world. About 350 crore of chicks are being placed annually in India and 4.85 million metric tonnes of broiler meat is produced every year (USDA, 2019).

The increased concentration of poultry enterprises on relatively small land areas have resulted in the production of large quantity of poultry manure (Silvat et al., 2009) which creates environmental, economic and social issues at times (Qian et al., 2014). One of the challenges facing livestock and poultry industry worldwide is manure management. Improper management and utilization of manure can contribute to environmental degradation, and ultimately be detrimental for human and animal population. Therefore a survey was undertaken to study the production and handling of broiler poultry litter.

Coimbatore, Tiruppur and Erode Districts of Tamil Nadu were selected, as these districts are in the Western Agro-climatic regions of Tamil Nadu with maximum number of broiler population.

The selected districts have maximum annual growth rate in broiler population and have more number of integrating companies, broiler parental breeding farms, broiler hatcheries, number of commercial broiler farms, few number of chicken processing plants, poultry input dealers and service providers, which favours a conducive environment for commercial broiler venture.

\section{Materials and Methods}

The survey was conducted in western agroclimatic zone of Tamil Nadu (Coimbatore, Tiruppur and Erode District) to study production and disposal status of broiler poultry litre. An interview schedule was prepared and free tested and used for collecting information such as Experience in commercial broiler farming, farm type, flock size, age of the bird, number of batches per year, floor type, watering system, litter management, quantity of litter produced, mode of disposal of BPL, value of the BPL, constraints in marketing the BPL, recycling of BPL and alternate usage of BPL. The data collected were analyzed and presented in table 1 .

\section{Results and Discussion}

\section{Broiler production management}

\section{Experience in commercial broiler farming}

$14.5 \%, 32.7 \%, 27.3 \%, 13.6 \%$ and $11.8 \%$ of interviewed respondents were having the experience of up to 5 years, 5 to 10 years, 10 15 years, 10 to 20 years and more than 20 years of broiler farming experience. The mean experience of the farmers was $13.6 \pm 0.82$ years and it was ranging from 6 months to 40 years.

\section{Farm type}

All the farmers (100\%) were on contract farming with any one of the vertically integrating companies operating in their locality and no farmer was independent. Morecki et al., (2013) reported all the farms where of commercial scale operations.

\section{Flock size}

$72.7 \%, 16.4 \%$ and $10.9 \%$ of the broiler farms in the surveyed geographical location were having up to 9000,9001 to 16800 and > 16800 respectively. The survey further revealed that means flock size was $9357 \pm 776.02$ and it was ranging from $1200-40,000.76 .3 \%$ of the respondents were having below 9000 birds per batch. Only $9 \%$ and $14.5 \%$ of the farms were with 10,001 to 15,000 and more than 15,001 birds per batch respectively. Bano et al., 
(2011) reported that the average flock size in the study area was 4033 birds. Yusuf and Malomo (2007) found that average number of birds for small farm size is 301, for medium farm size is 740 , while that of large size is 2288.

Moreki et al., (2013) reported that majority of poultry operations $(64 \%)$ where of small scale, followed by $20 \%$ of medium scale and $16 \%$ of large scale operation.

Forty nine per cent of respondents had the batch size of 500-1000 birds. Whereas, 29.00 per cent of respondents had the batch size of 1000-5000 birds per batch followed by 22.00 per cent of respondents were having the batch size of 1500- 2000 birds per batch.

\section{Age of the bird}

$52.7 \%$ of the farmers were marketing the birds after 41 days of age, $24.5 \%$ of the farmers marketed the birds at the age of 36 to 40 days and $22.7 \%$ of the farmers were found to be marketing the birds below 35 days. The average age at which broilers were marketed was $40+40$ days which was ranging from 32 to 45 days during the period of survey.

\section{Number of batches per year}

The mean number of batches per year was 4.3 \pm 0.06 with a range of 3 to 5 batches per year. Equal proportion of farmers $(44.5 \%)$ were rearing 4 and 5 batches of broilers per year where as $10.9 \%$ of the respondents had only 3 batches per year.

Badubi et al., (2004) reported that on average, small-scale producers had 4-5 production cycles per annum with an interval of 2-3 weeks between batches. Farooq et al., (2013) observed that on average poultry farmers raised 4.97 flocks per year and interval between two batches was found to be 21 days.

\section{Floor type}

The investigation revealed that commercial broilers farms located in the surveyed geographical locality were with cement floor to the extent of $49.1 \%$ and mud floor was found to be in $50.9 \%$ of the farms. Kumar et al., (2018) surveyed commercial broiler farms and revealed that cemented floor, earthen and brick paved floor were observed in 59.50 per cent of broiler farms, 29.50 per cent and 11.00 per cent respectively.

\section{Roof type}

The common roofing material used in the broiler farms surveyed was found to be tiles $68.2 \%, 19 \%$ of the farms had galvanized iron sheets as roofing material and $12.7 \%$ of farmers provided asbestos as roofing materials. Kumar et al., (2018) observed that the roof of broiler sheds in the surveyed area were asbestos roof, iron sheet, thatched and tiled to the proportion of 66.50 per cent $18.00 \%, 15.00 \%$ and $0.50 \%$; respectively. Whereas, Islam et al., (2014) observed that 85 per cent farms had broiler houses with gable type roof with corrugated iron sheet. Similarly, Hedge and Shridhar (2012) reported that majority of the farms $(74.07 \%)$ using $d$ tiled roof for housing of broiler birds in Tamil Nadu. Sridharan (2017) noticed that broiler farms were found to be with thatched, tiled and asbestos in $57.9 \%, 29.5 \%, 12.6 \%$ of farms surveyed respectively

\section{Feeding system}

All the farmers were found to have semi automatic circular drum feeder without exception no farmers was using open 1 trough or automatic feeders. Regarding the types of feeders used for feeding of birds, it was found that 64.00 per cent respondents were using manual feeders for feeding of the birds. Whereas, 35.00 per cent and 1.00 per cent 
respondents were using automatic and semiautomatic feeders for feeding of the birds at their farms, respectively. Singh et al., (2010) reported that farmers having farm size above 8000 birds were found using semi-automatic feeders. Hossein et al., (2012) found that in the study of feeding system, the good group has the highest percentage of using automatic systems (86/60) and the weak group has the highest percentage of using manual systems.

\section{Source of the feed and diet base}

All the respondents were found to use the feed supplied by integrator and no farmer was using the self manufactured feed. In the surveyed locality all the farms provided with concentrate feed from chick to marketing age of bird with feed constituted by corn and soybean as primary ingredients. It was observed that 61.00 per cent of respondents were using commercial feeds to feed their broiler birds, whereas, 39.00 per cent respondents were using both commercial and home-made feeds to feed their birds. Singh et al., (2010) reported that 68.7 per cent farmers purchased readymade feed, 4.0 per cent were found to have their own feed manufacturing unit and 27.3 per cent prepared the feed by mixing the purchased concentrates and energy feed ingredients

\section{Feed type}

$70 \%$ of the farmers in surveyed geographical area were found to be using crumble type of feed and $30 \%$ of the farmers were using mash form of feed for the their birds.

\section{Watering system}

$70 \%$ of the farms in the investigated geographical area had automatic bell type drinkers and $30 \%$ of the farms were found to be dispensing water to their birds with the help of nipple. No farm was with neither open pan nor automatic drinkers were found in any of the farms.

\section{Feed type}

Most of the respondents $(61.00 \%)$ were using pellet form of feed for feeding of their broiler birds. However, 38.00 per cent and 1.00 per cent respondents were using mash + pellet and mash forms of deed only for feeding of their birds.

\section{Watering system}

It was found that 60.00 per cent respondents were using manual waterers for drinking of the birds at their farms. The remaining 40.00 per cent respondents were using automatic waterers for drinking of the birds at their farms.

\section{Litter management}

The mean quantity of the litter material that is to be spread was $9333.27 \pm 2.64 \mathrm{~kg}$ it was ranging from $1500 \mathrm{kgs}$ to $40000 \mathrm{kgs}$ per farm per batch. The mean cost spend for litter material was found to be Rs. 2/- per $\mathrm{kg}$. All the respondents were found to spread the require quantum of litter material only once no farm had the custom of topping of litter material. Frequency of racking of litter during the period of rearing was more than one in $91.5 \%$ of the farms studied and $12.3 \%$ of the farm had less than one racking frequency. No farmer was found to use any litter preservatives during the course of broiler production cycle.

\section{Post production handling of Broiler poultry Litter}

\section{Quantity of litter produced}

The mean quantity of broiler poultry litter produced per batch was $22.3 \pm 2.64$ tonnes and it was ranging from 5 to 90 tonnes. 
Table.1 Survey on manure management practices among broiler farmers

\begin{tabular}{|c|c|c|c|c|}
\hline Sl. no & Parameter & Category & Frequency & percentage \\
\hline \multirow[t]{5}{*}{1} & \multirow[t]{5}{*}{ Experience of farmers (years) } & $<5$ & 16 & 14.5 \\
\hline & & 5 to 10 & 36 & 32.7 \\
\hline & & 10 to 15 & 30 & 27.3 \\
\hline & & 15 to 20 & 15 & 13.6 \\
\hline & & $>20$ & 13 & 11.8 \\
\hline \multirow[t]{3}{*}{2} & \multirow[t]{3}{*}{ Integrator } & Shanthi feeds & 68 & 61.8 \\
\hline & & RMP farms & 32 & 29.1 \\
\hline & & Others & 10 & 9.1 \\
\hline \multirow[t]{4}{*}{3} & \multirow[t]{4}{*}{ Flock size (Nos.) } & $<5000$ & 37 & 33.6 \\
\hline & & 5001 to 10000 & 47 & 42.7 \\
\hline & & 10001 to 15000 & 10 & 9.09 \\
\hline & & $>15001$ & 16 & 14.5 \\
\hline \multirow[t]{3}{*}{4} & \multirow[t]{3}{*}{ Marketing age of broilers (days) } & $<35$ & 25 & 22.7 \\
\hline & & 36 to 40 & 27 & 24.5 \\
\hline & & $>41$ & 58 & 52.7 \\
\hline \multirow[t]{3}{*}{5} & \multirow[t]{3}{*}{ No. of batches/Year } & 3 & 12 & 10.9 \\
\hline & & 4 & 49 & 44.5 \\
\hline & & 5 & 49 & 44.5 \\
\hline \multirow[t]{2}{*}{6} & \multirow[t]{2}{*}{ Floor type } & Cement & 56 & 50.9 \\
\hline & & Mud & 54 & 49.1 \\
\hline \multirow[t]{3}{*}{7} & \multirow[t]{3}{*}{ Roof type } & Tiles & 75 & 68.2 \\
\hline & & Asbestos & 14 & 12.7 \\
\hline & & Metal & 21 & 19.1 \\
\hline \multirow[t]{2}{*}{8} & \multirow[t]{2}{*}{ Type of feed } & Mash & 33 & 30 \\
\hline & & Crumble & 77 & 70 \\
\hline \multirow[t]{2}{*}{9} & \multirow[t]{2}{*}{ Feed additive } & Yes & 15 & 13.6 \\
\hline & & No & 95 & 86.4 \\
\hline \multirow[t]{2}{*}{10} & \multirow[t]{2}{*}{ FCR } & $<1.5$ & 31 & 29.2 \\
\hline & & $>1.5$ & 75 & 70.8 \\
\hline \multirow[b]{2}{*}{11} & \multirow[t]{2}{*}{ Watering system } & Automatic & 77 & 70 \\
\hline & & Nipple & 33 & 30 \\
\hline \multirow[t]{2}{*}{12} & \multirow[t]{2}{*}{ Water medications } & No & 66 & 60.0 \\
\hline & & Yes & 44 & 40.0 \\
\hline \multirow[t]{2}{*}{13} & \multirow{2}{*}{$\begin{array}{l}\text { Frequency of racking } \\
\text { (No. of day } / 42 \text { ) }\end{array}$} & $<1$ & 13 & 12.3 \\
\hline & & $>1$ & 97 & 91.5 \\
\hline 14 & Litter material & Coir Pith & 105 & 95.5 \\
\hline & & Rice Husk & 5 & 4.55 \\
\hline 15 & Litter produced (tonnes) & $<10$ & 25 & 35.2 \\
\hline & & 10 to 20 & 26 & 36.6 \\
\hline & & $>20$ & 20 & 28.2 \\
\hline
\end{tabular}




\begin{tabular}{|c|c|c|c|c|}
\hline \multirow{5}{*}{16} & \multirow[t]{5}{*}{ Mode of disposal } & To farmer & 22 & 20.0 \\
\hline & & Trader & 23 & 20.9 \\
\hline & & Self-use & 11 & 10.0 \\
\hline & & Farmer + Self & 30 & 27.3 \\
\hline & & Farmer + Trader + Self & 24 & 21.8 \\
\hline \multirow{5}{*}{17} & \multirow[t]{5}{*}{ Self-use handling } & No & 45 & 40.9 \\
\hline & & Amendments & 1 & 0.91 \\
\hline & & Fresh & 25 & 22.7 \\
\hline & & Delayed use & 37 & 33.6 \\
\hline & & Depends on Rain & 2 & 1.82 \\
\hline \multirow[t]{2}{*}{18} & \multirow[t]{2}{*}{ Method conservation } & Composting & 6 & 5.5 \\
\hline & & Open piling & 104 & 94.5 \\
\hline \multirow[t]{2}{*}{19} & \multirow[t]{2}{*}{ Value of the BPL (Rs.per bird) } & $<1$ & 60 & 73.2 \\
\hline & & $>1$ & 22 & 26.8 \\
\hline \multirow[t]{2}{*}{20} & \multirow{2}{*}{$\begin{array}{c}\text { Constraints in marketing the } \\
\text { BPL }\end{array}$} & Poor market & 96 & 88.1 \\
\hline & & Water Availability & 13 & 11.9 \\
\hline \multirow[t]{2}{*}{21} & \multirow[t]{2}{*}{ Recycling } & No & 109 & 99.1 \\
\hline & & Yes & 1 & 0.9 \\
\hline \multirow[t]{2}{*}{22} & \multirow[t]{2}{*}{ Alternative use } & No & 105 & 95.5 \\
\hline & & Yes & 5 & 4.5 \\
\hline \multirow[t]{3}{*}{23} & \multirow{3}{*}{ Replacement level of fertilizer } & Partial & 43 & 39.1 \\
\hline & & Full & 58 & 52.7 \\
\hline & & NA & 9 & 8.18 \\
\hline \multirow[t]{2}{*}{24} & \multirow[t]{2}{*}{ Method of manuring } & Direct & 59 & 90.8 \\
\hline & & Composting & 6 & 9.2 \\
\hline \multirow[t]{2}{*}{25} & \multirow[t]{2}{*}{ Value addition of BPL } & No & 109 & 99.1 \\
\hline & & Yes & 1 & 0.91 \\
\hline \multirow[t]{3}{*}{26} & \multirow[t]{3}{*}{ Knowledge score (\%) } & $<40$ & 28 & 25.5 \\
\hline & & $40-80$ & 50 & 45.5 \\
\hline & & $>80$ & 32 & 29.1 \\
\hline
\end{tabular}

The investigation further revealed that $35.2 \%$ of the farms have been found to be producing less than 10 tonnes of BPL, $36.6 \%$ of the farms were producing 10 to 20 tonnes and $28.2 \%$ of the farms were found to produce more than 20 tonnes of BPL per batch. The mean quantity of the BPL produced per bird was worked out to be $2.34 \pm 0.3 \mathrm{~kg}$ in a production cycle.

\section{Mode of disposal of BPL}

20.9 of the farmers were found to market the BPL to the traders operating in the locality
$20 \%$ of farmers were found to market the BPL directly to the farmers, $10 \%$ of the farmers only had land resources to make use of the entire quantity of BPL produced in the farms. $27.3 \%$ of the respondents were found to sell BPL to the local farmers and use whenever the need for their agricultural operation and 21.8 $\%$ of the respondents were found to sell out the BPL directly to the farmers as well as the traders in addition to use in their farming operation.

Mehta et al., (2008) reported that $2.4 \%$ of small farmers and $12.4 \%$ large farmers were 
using broiler litter immediately. Mehta et al., (2008) reported that only $4.58 \%$ of large farmers and $13.65 \%$ of small farmers were found to be using BPL in their own farm. $0.24 \%$ of small farmers and none of the large farmers were found to dump BPL in the farm.

$45 \%$ of the respondents were found not at all utilizing BPL in the farming operation. Among the farmers using BPL for their agricultural operation, 33.6 of the respondents were found to be broadcasting the BPL in their land and after the advent of rainfall, it is ploughed out $22.7 \%$ of the respondents were found to use BPL as fresh mixed with other farm waste such as cow dung. $1 \%$ of the farms was found to utilized the BPL with amendments like microbial inoculum the BPL utilization was found to be affected by rainfall in $1.82 \%$ of the respondents. Only $5.5 \%$ of the farmers were having the composting as mode of conserving nutrients in BPL. No farmer was found to produce biogas out of BPL.

All the farmers without any exception had the practice of removing BPL as early as possible after marketing the broiler chicken. $1.1 \%$ of the farmers in the surveyed farms were recycling the BPL for another batch of birds without any treatment. Only $4.5 \%$ of the farmers were found to using BPL for operations like mushroom production, etc other than agricultural operations. $58.8 \%$ of the respondents were found to use BPL as sole source of ferlitizers operations, $41.5 \%$ of the farmers were found to replace the usage of chemical fertilizer partially with BPL. Morecki et al., (2013) reported that manure collected is supplied to farmers in need for their agricultural operations. Morecki et al., (2013) reported that $80 \%$ litter produced had been disposed of to other farmers. While $16 \%$ of litter produced is used by farmers themselves. $4 \%$ of manure was found to be land filled. Majority of the farmers were found to use BPL as fresh directly broadcasted in the agriculture land immediately after removal and ploughed on the advent of rain and 9.2\% of the farmers were found to use the BPL as composted Only one respondents out of 110 farms surveyed was found to attempting value addition of BPL (0.91\%).Chapman, (2007) stated that litter usage as fertilizer in the farmers field and marketing to the farmers to be used as fertilizers. Chapman, (2007) proposed that poultry litter might be used as source of energy, feed additives and chemical additives.

\section{Recycling of BPL}

Mehta and Nabiyar reported that it is beneficial and economical, if managed properly, and recycling had become a standard in the poultry industry. As poultry litter is reused, the chance of nutrient or pathogen contamination to waterways is reduced.

Mehta et al., (2008) reported that no information could be collected on BPL as fresh organic fertilizers, composed of BPL, brick building, fuel bricks and mushroom substrate.

\section{Value of the BPL}

$73.2 \%$ of the farmers were fetching more than 1 rupee per $\mathrm{kg}$ of BPL produced and $26.8 \%$ of farmers were getting 1 only less than 1 rupee per $\mathrm{kg}$ of BPL.

\section{Constraints in marketing the BPL}

$88.1 \%$ of the respondents ranked the market rate for BPL as the primary and foremost constraint in marketing the BPL produced in their farms. Another $11.9 \%$ of the farmers had found water availability and rainfall for agricultural operations as deciding factor of the remuneration for the BPL produced in the farm. 


\section{Knowledge on BPL}

The mean knowledge level on BPL among the respondents was $61.09 \%$ it was ranging from 20 to $100 \%$. $45.5 \%$ of the respondents had more than 40 to $80 \%$ knowledge level, $29.1 \%$ of the respondents had found to have knowledge level of more than $80 \%$ and $25.5 \%$ of respondents had only below $40 \%$ of the knowledge on basic characters of BPL. FAO (2012) acknowledged that knowledge on manure is very essential for effective waste management programme. Morecki et al., (2013) stated that lack of knowledge among farmers on waste management was one of the factors led to poor management of litter. The respondents are not aware about the scientific management of broiler poultry litter and The farmers are not adapting rational techniques on management of broiler poultry litter to get maximum benefit from the broiler farming, it can be concluded that a no definite trend was observed on utility of Broiler poultry litter by different categories of farmers.

\section{References}

Kumar, A, Sahu1, S.P., Singh, S.K., Sinha, M., Das Arya S.K. and Anish Kumar. (2018) Broiler Management and Feeding Practices Adopted by the Farmers of Bihar Int.J.Curr.Microbiol.App.Sci Special. 7: 5132-5139 http://www.ijcmas.com
Mehta, R., Narood, C.A., and Tiongco., M.M. 2008. Livestock industrialization, trade and social - health - environment impacts in developing countries - a case of poultry sector. Research and information system for developing countries.

Qian, X., Shen, G., Wang, Z., Guo, C., Liu, Y., Lei, Z., and Zhang, Z. 2014.Cocomposting of livestock manure with rice straw, Characterization and establishment of maturity evaluation system. Waste Manage. 34: 530-535

Report, 2019. Indian Poultry Market: Industry Trends, Share, Size, Growth, Opportunity and Forecast 20192024. Accessed from https://www.researc handmarkets.com/reports/4763054/indi an-poultry-market-industry-trendsshare

Satapathy, D., Sharma, A., Paswan, J.K., Sarkar, S and Varun, T.K. 2017 Economic Broiler Farming: Scope and Limitations Indian Farmer. 4(5): 393405.

Silva, M.E., Lemos, L.T., Cunha-Queda A.C., and Nunes O.C. 2009.Co-composting of poultry manure with low quantities of carbon-rich materials. Waste Manag. Res. 27: 119-128.

USDA, 2019. Livestock and Poultry: World Markets and Trade, United States Department of Agriculture Foreign Agricultural Service. April 9, 2019.

\section{How to cite this article:}

Thirunavukkarasu, M., K. Sivakumar, V. Ramesh, M. R. Purushothaman, N. Murali and Mahimairaja, S. 2019. A Survey Profile on Broiler Poultry Litter Production and Disposal in Tamil Nadu, India. Int.J.Curr.Microbiol.App.Sci. 8(12): 782-789.

doi: https://doi.org/10.20546/ijcmas.2019.812.102 